\title{
Analysing nineteenth century military building typologies: an Australian perspective
}

\author{
N. K. Boyd ${ }^{1} \&$ J. Rice ${ }^{2}$ \\ ${ }^{1}$ Architectural Historian, Australia \\ ${ }^{2}$ Architect, Australia
}

\begin{abstract}
Australia retains a considerable legacy of substantial but austere nineteenth century buildings designed by the British Royal Engineers to serve the military and convict establishments, buildings which ranged in use from official residences, military barracks and commissariat stores to steam-powered workshops at naval dockyards. In the 1850 s the separate Australian colonies inherited these buildings, which they continued to use for a range of administrative and defence purposes. With the Federation of Australia in 1901 many of these complexes were then turned over to the Commonwealth government, beginning a third phase of use. The range of building types erected in Australia to designs by the Royal Engineers has been traced and surviving examples of different typologies identified. Precedents for a number of the building forms have been analysed, in an attempt to determine whether the building form and planning originated in England or in the colonies. The military engineers travelled widely during their careers and by necessity had to adapt standard building forms to suit local conditions. Forms and technical innovations trialled in the colonies came into regular usage and continue in use today. Gaining an understanding the principal characteristics of the military building types used in the colonies, including their structural types, construction methods and the carefully worked out methods of daylighting, shading and passive ventilation, is of considerable benefit when determining new uses for surplus assets.
\end{abstract}

Keywords: colonial architecture, standard military buildings, construction types, cast iron, Royal Engineers, William Denison. 


\section{Introduction}

This paper traces the use of standard military building forms by the British in their numerous colonies, with a particular focus on the origins of the designs of surviving Australian examples. Australia, originally a series of separate British penal colonies progressively established from 1788, has a considerable legacy of substantial but austere buildings designed by the British Royal Engineers.

In our research work undertaken for the Conservation Management Plan for the World Heritage listed settlement at Kingston on Norfolk Island in the South Pacific we attempted to trace the origins of the various building forms, as these forms were familiar to us, as they occur at other Australian penal stations. We then attempted to assess the rarity of surviving building stock by placing it in both a national and an international context. Studies of colonial architecture in Australia have largely concentrated on the transmission of Georgian architecture directly from Great Britain, yet during our comparative analysis it became clear that there were similar buildings surviving in other former colonies that were more likely to have served as a precedent, having already been adapted to suit a warmer climate. We also found that the development of standard building forms by military engineers, and their pioneering use of new technologies, has not been included in mainstream architectural histories.

In addition to their work during military campaigns, buildings designed by the Royal Engineers were constructed throughout the British Colonies including Gibraltar and Malta in the Mediterranean, India, Ceylon (Sri Lanka), Hong Kong, Malacca (Penang) and Singapore, Canada (including Nova Scotia), Bermuda, the West Indies, Guyana, South Africa, Australia and New Zealand. Some of the most substantial of these structures survive today and continue to be used, although mostly no longer utilized by the British military. To date there has not been a comprehensive study of these colonial buildings and many of the architectural drawings sent to be Colonial Office remain unpublished but survive in the National Archives, London, England. Not only do the building types reappear, but the names of the British colonial settlements were also repeated, giving a clear indication of their British origins. Settlements were named for the Royal family or influential politicians. Today there is a Kingston in Nova Scotia, on Lake Ontario in Canada, in Jamaica and on Norfolk Island, all of which contain buildings designed by the Royal Engineers.

During the 1830s papers presented by Royal Engineers in London began to be published as a journal, providing details of materials testing, building designs and technological developments for use by engineers working throughout the British colonies worldwide. Descriptions of the capability of building materials and buildings techniques, such as the construction of breakwaters, timber preservation and damp-proofing, as well as instructions regarding surveying and mapping techniques could be found in the technical papers. Colonisation meant that Britain could remain supplied with necessary building and ship building materials, particularly timbers. The Royal Engineers identified the capacity of a range of colonial building materials. William Thomas Denison's extensive tests 
on colonial timbers from Canada, Tasmania and New Zealand carried out earned him the Telford Medal in 1837.

Prior to the publishing of technical papers there was a direct correlation between the adoption of particular building forms in the Australian colonies and the postings of the military officers who designed them. Standardised forms initially made their way to Australia via commanding officers. Joseph Foveaux was instrumental in the development of public works in both New South Wales (NSW) and on Norfolk Island, having served at Lieutenant Governor of the latter from 1800-1804. Between his term on Norfolk Island and his term in Sydney Foveaux returned to England where he would have seen recently completed buildings. Lachlan Macquarie, appointed Governor of NSW in 1809, and his aide-de-camp, Lieutenant John Cliffe Watts, had both served in the West Indies, Macquarie in the 1780s and Watts in 1805-1811. Macquarie had also served in Canada, New York, India and Egypt so had been exposed to a wide range of building types erected by the British. Until the arrival of free settlers and the Royal Engineers in the 1830s successive Australian Governors had to rely on military officers, and occasionally convicts, with an aptitude for design.

Whilst there are no technical papers specifically describing buildings erected for the Convict Establishment in Australia, the Royal Engineers papers are held in Australian libraries, indicating their use here. The influence of published designs such as Sir Charles Smith's system of tropical barracks; descriptions of the dockyards at Woolwich and Portsmouth by William Denison and Henry James as well as Joshua Jebb's recommendations for colonial prisons can all be traced in buildings erected in the Australian colonies. Our comparative study for Kingston, Norfolk Island, indicates that a number of building forms had been standardised for some decades before the arrival of the Royal Engineers and the publication of their journal. Officers were familiar with these forms and transplanted them from one colony to another, carrying plans with them.

\section{Barracks and military hospitals}

The building form that most clearly demonstrates the transfer of building forms from one colony to another is the West India barrack, utilised for both military hospital and barracks. Pedro Guedes of the Queensland University of Technology notes that:

Vernacular forms of Caribbean building with deep verandahs had influenced the design of 18th century barracks and hospitals. Lord Combermere used his authority as Commander-in-Chief, Leeward Islands to highlight certain features of this tradition, giving them official blessing. He also mused upon the economies of using iron and called upon medical opinion for scientific backing. The use of galleries [verandahs] was mandated for all Caribbean military buildings by a circular from the Secretary for War and the Colonies, Lord Bathurst, narrowing the options for fine judgements in design further still. Wellington as Master General of 
the Ordnance saw the use of iron for colonial military buildings as a method of imposing absolute uniformity and central control...(Guedes [1]).

Uniformity did not occur quite as intended, as the ever practical Royal Engineers continued to adapt and improve the design of barracks, making changes to suite the locality, climate and available building materials. Building forms used in the Caribbean were soon employed in other colonies. Post 1800 a transition can be observed in the West Indies from the use of a solid ground floor or arcade with verandah above to the two-storey verandah form that became a standard. It was only in the most substantial barracks, such as those in India, that the use of arcades continued. At St Ann's Garrison, Barbados, (part of the Bridgetown World Heritage Site), the sequence of hospital and barrack buildings dating from 1803 to 1831 survive, demonstrating this transition. The justification for design changes was the need to combat disease by increasing the amount of fresh air, however the decision was also a practical one. Verandahs supported by columns or posts were more economical in terms of materials and could be erected using freely available local timbers. Timber was plentiful in the tropics. The building of arcades or colonnades required good quality bricks or a suitable building stone. Both required a range of skilled trades that were not always available in the colonies, particularly when forced labour was used.

By the time the standard West India barrack was approved in London in 1824 the underlying design principles had already spread to other colonies. The similarity between the General Hospital in Macquarie Street, Sydney, NSW erected in 1811-14 (figure 1) with the naval hospitals designed by Edward Holl for Jamaica and Bermuda circa 1818 demonstrates that many of the features proposed by Colonel Charles Smith to the Board of Ordnance in 1824 as standard for tropical barrack were already in regular use in a number of British colonies including New South Wales (NSW) in Australia.

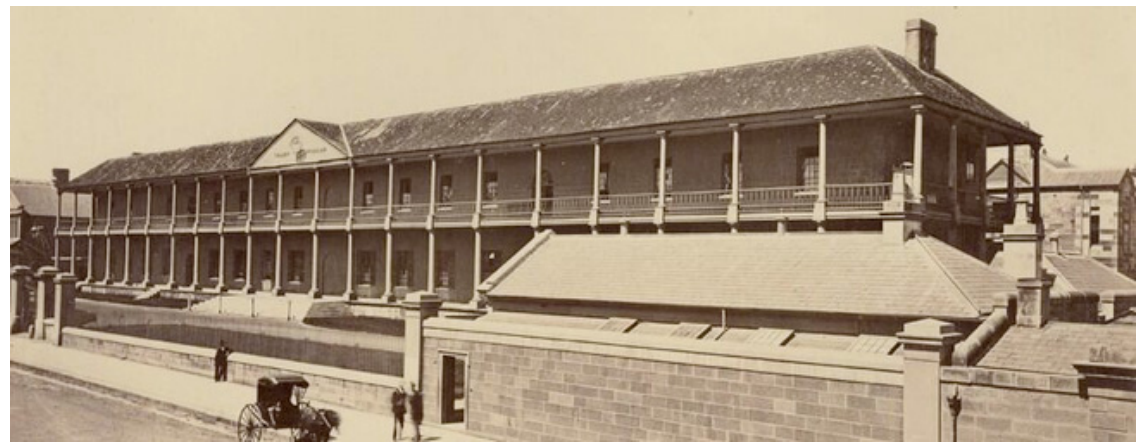

Figure 1: 1870 view of the now demolished central block of the Rum Hospital in Sydney, originally erected 1811-1814. (ML SPF/176 State Library of NSW.)

The Naval Hospital at Port Royal, Jamaica survives today and has been included in the proposed World Heritage listing for the Underwater City of Port 
Royal. The hospital is a two-storey prefabricated building built by slave labour in 1818 under the direction of the Royal Engineers to replace an earlier hospital built in the 1740s (and destroyed by fire in 1812). Its designer was the English naval architect Edward Holl. The prefabricated iron components were made in Bradford, England and shipped to Jamaica, at great expense to the British taxpayer. The cast iron framework was then infilled with locally made brickwork. Holl also employed encircling verandahs at the Royal Naval Hospital (1818) and the Commissioners Residence (1822-23) at the dockyard in Bermuda. His earlier design for the Royal Naval Hospital at Great Yarmouth, Norfolk, England (1811) was a substantial brick building, with its central breakfront and single storey arcade, and was more typically Georgian in architectural character. Holl's choice to include the encircling verandahs in the colonial examples was a deliberate one, indicating knowledge of colonial architecture. Contemporary Indian hospitals, such as the Madras Naval Hospital only had a two-storey colonnade to the main elevation whereas plantation houses in the West Indies and Louisiana had adopted encircling verandahs.

In Sydney five hospital ward blocks were built between 1812 and 1820, three of which survive. The hospital at Parramatta and the central block of the Sydney General Hospital (or Rum Hospital) (figure 1) have been demolished. Two Rum Hospital pavilions remain in use and retain evidence of their original configuration of encircling verandahs. The southernmost pavilion is now the headquarters of Sydney Living Museums, (having been converted into the Sydney Mint in the mid 1850s and into a museum in the 1970s). The northernmost pavilion was taken over by the fledging NSW Parliament in the 1850s and still forms the centre of the Parliament House complex. The larger central block was demolished to make way for a substantial new pavilion hospital in the 1880s. The Military Hospital on Observatory Hill in Sydney (designed by Lieutenant Watts) was converted into a school in the 1850s by Mortimer Lewis, who considerably altered the external appearance. Paintings survive showing the original configuration. Watts left the West Indies in 1811 before the buildings designed by Holl were erected, indicating that there is as yet an earlier, unidentified precedent for these hospital and barrack designs.

Unlike the naval hospitals in the West Indies, the hospital blocks in Sydney were not prefabricated, but were built using local material: stone quarried nearby, lime burnt from shells, hardwood lumber and timber shingles. Turned timber, rather than cast iron, was employed for the columns, as good quality hardwoods were widely available. Lumberyards had been established where the convicts worked prefabricating building components and furniture. In the Caribbean it was initially military hospitals that were erected using prefabricated iron components. Two hospitals were built Lieutenant H R Brandreth's supervision, Antigua in 1827 and Barbados in 1828. Brandreth's drawings of the ironwork components that he had helped develop appeared in the Royal Engineers Journal in 1838, as a commentary to Smith's standard barrack design (Brandreth [2]).

The standard West India barrack design adapted features of the local vernacular already used by planters in the Caribbean and Louisiana for their 
residences. Raising the ground floor and providing fresh air and cross ventilation, it was believed, would lessen the spread of disease spread by miasmas or foul air. When describing his standard tropical barrack, Colonel Smith had observed differences in mortality rates when slaves were no longer accommodated in vernacular huts raised above ground level but were allocated 'board and shingle huts' (Smith [3]).

\subsection{Military barracks}

Two substantial examples barracks erected between 1810 and 1830 survive in Australia and are still in use: the Lancer Barracks at Parramatta and the Anglesea Barracks in Hobart. Lieutenant Watts is believed to have designed individual buildings for both complexes. The more substantial Wynyard Barracks in Sydney, which had been commenced in 1792, was demolished in the 1840s, following the relocation of the military to a new, larger complex in Paddington, Sydney. The large barrack blocks at Wynyard were erected in 1808-10. Verandahs were employed at each complex. Georgian architectural forms had been adapted to suit a warmer climate, as had already occurred in the Caribbean where Watts had previously been stationed.

It was not until the arrival of the Royal Engineers in Australia in 1835 that the technological innovations associated with the standard tropical barracks were implemented in the Australian colonies. George Barney, who was posted to Sydney as Commanding Royal Engineer in Sydney in 1835, had previously worked in Kingston, Jamaica. His architectural drawings of Up Park Camp prepared in 1824 survive in the National Archives in London. Barney is known to have made a point of studying contemporary buildings, he recounted having 'inspected several gaols in and about London preparatory to my coming here [to Sydney] (Barney [4]). It was probably Barney who made sure that a set of the West India barrack drawings were kept at the Royal Engineers Office in Sydney.

John Weiler, in his paper on the transfer of building technologies by the Royal Engineers, notes that this pioneering use of cast iron was soon forgotten (Weiler [5]). The use of cast iron columns can still be seen in the external verandahs of Australian barracks in the 1840s and in English barracks erected in the 1850s. Smith's 'Uniform System' of West Indian barracks continued to be influential until the publication of Florence Nightingales Notes on Hospitals in the late 1860s. The influence of Smith's published designs can be seen in Australia the sequence of barracks erected following the arrival of the Royal Engineers in 1835, starting with the Officers' Quarters and Hospital of the New Military Barracks complex on Norfolk Island (1835-37) which survive today.

In NSW, the Royal Engineers built the Soldiers and the Officers Barracks at Newcastle (now part of the James Fletcher Hospital) (completed in 1842) and the substantial Soldiers Barracks at Victoria Barracks in Sydney (1841-1846) (figure 2). Changes were made to the design in NSW where the climate was less tropical and death from fevers less frequent. The raised ground floor, which can be seen at both the Old and New Military barracks at Kingston, Norfolk Island, was omitted in the large barrack complexes erected in Sydney (Victoria Barracks) and Newcastle in the 1840 s, as was the encircling verandah. The 


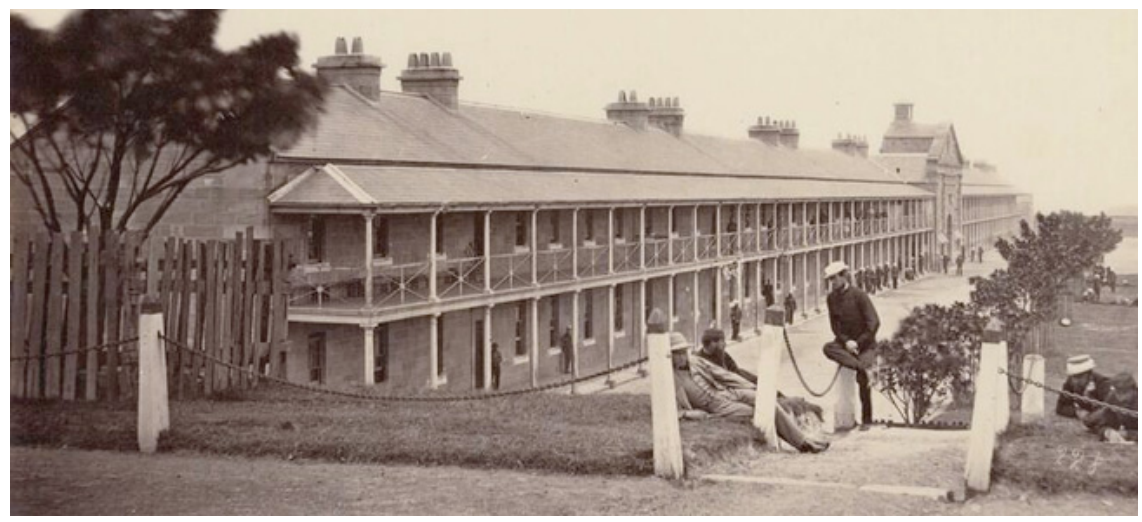

Figure 2: December 1870 view of the main block of Victoria Barracks, Sydney. (ML SPF/23 State Library of NSW.)

hospital block at Victoria Barracks retained the raised ground floor. Cast iron columns for the Newcastle barracks were ordered from England but took so long to arrive that timber was substituted. When it finally arrived, the ironwork was redirected for use at the Victoria Barracks in Sydney. Victoria Barracks is still in use as a barrack complex, having been transferred to the colony of NSW and then to the Commonwealth of Australia. The former barrack at Newcastle in NSW has seen various uses, most recently as a hospital.

Budget cuts in 1842 resulted in a reduction in the number of clerks of works in the Royal Engineers Department in Sydney. Amongst the staff let go were Henry Ginn, John Frederick Hilly and his subsequent partner Richard Lambeth. These men then set themselves up as architects and surveyors, choosing to remain in the Australian colonies. The idea to use cast iron columns was transferred to civil architecture by Henry Ginn, George Barney's protégé, who tendered for cast iron columns for the public library in Sydney in 1844. Hilly and Lambeth likewise applied their knowledge of building construction gained whilst employed in the Royal Engineers Department.

More occasionally Royal Engineers who had served in the colonies applied practical knowledge gained overseas on their return to England. William Denison had not only served abroad, but he also reviewed designs for the Royal Engineers journal and this experience proved invaluable. Denison designed the substantial marine barracks at Woolwich in the early 1840s that incorporates a two-storey arcade and raised ground floor. The Survey of London notes that this colonial form was without precedent in England, only the gate lodges survive today.

During his subsequent terms as Governor of Tasmania and then NSW, Denison continued to promote buildings designed by the Royal Engineers as models.

The people in the adjoining colonies are beginning to find out the advantage of having an officer of Engineers as Governor. I have had references made 
to me from Sydney, Melbourne, and Adelaide, not merely from the Government, but from the Town Councils, applying through the Government for my advice on various subjects, such as the construction of docks, the supply of water, the construction of canals, the formation of a harbour (Denison [6]).

In the design of the Fitzroy dock at Cockatoo Island in Sydney Harbour, particularly the use of steam power to pump the dry dock and to power the adjacent dockyard workshop, Denison directly applied his personal knowledge of English installations he had been supervising at Woolwich and Portsmouth. The steam workshop on Cockatoo Island in Sydney is almost identical to the drawings of the workshop at the Steam Factory at Royal Dockyard in Portsmouth illustrated in the Professional Papers in 1853 (James [7]).

Occasionally barracks erected in England included verandahs or external galleries more commonly found in colonial examples. The main barrack block at the St Georges Barracks at Gosport (1856-59) included wide verandahs intended for use as an exercise area in wet weather. The married quarters at the Hounslow barracks erected in 1860 included single roomed apartments accessed from external galleries (a feature later used in public housing). The St Georges Barracks has been converted into maisonettes whereas the Hounslow barracks is still in use as a barrack (however the accommodation has been upgraded substantially). Barracks with two storey verandahs dating from the 1850 s were also erected at the Preston Barracks, Brighton and at Aldershot in Hampshire. At Aldershot a series of cavalry barracks with two storey verandahs were built, soldiers accessed their barrack above the stables from an external stair to the verandah. Calls to improve barrack accommodation in the 1860 s led by Florence Nightingale seem to have put paid to these experiments.

\subsection{Guard houses}

Like the Wynyard Barracks, Sydney, Australia, the now demolished George Street Guardhouse (by 1813) included a verandah (figure 3). Verandahs were an occasional feature of English Georgian architecture, but were primarily used for private enjoyment, located to the garden front.

Precedents appear in Portuguese architecture where verandahs provided a covered area for servants to work outside or to guardhouses, as in the main square in Obidos, Portugal. The verandah came to be widely used in colonial military buildings, however to maximise observation, verandahs were relocated to the main front of the building. The guardhouse designed by the Royal Engineers at the Glacis Barracks at Halifax in Canada and erected in 1799 is similar to the sandstone example erected on Cockatoo Island in Sydney Harbour, Australia in the 1840s indicating that there were standard designs in existence. The Halifax example has been demolished whilst the example on Cockatoo Island is in ruins. Standard drawings have yet to be located. Identical guardhouses with verandahs can be found at barracks at Exeter and Canterbury in England. 


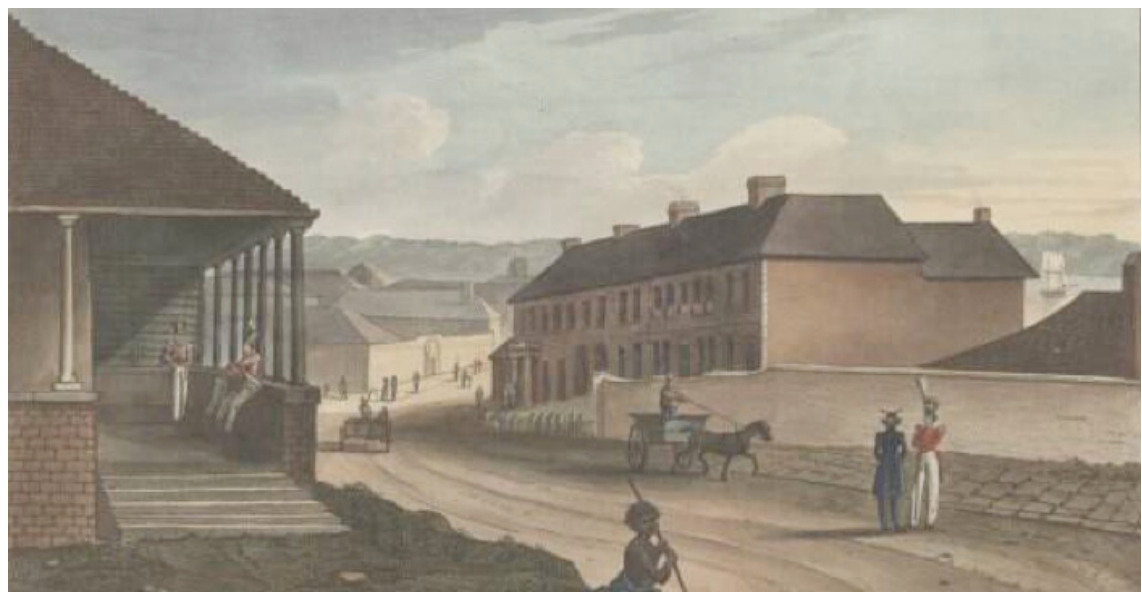

Figure 3: George Street Guard House, from a View from the Sydney Hotel, by Augustus Earle circa 1825. (National Library of Australia.)

\section{Official residences}

Architectural drawings survive in National Archives in London prepared between 1800 and 1850 for Government Houses in various colonies and in the Channel Islands. Within each colony the Government Houses are an example of the highest standard of accommodation provided, providing a stark contrast to the hulks or convicts barracks, the lowest form of accommodation provided. Because of their high standard of design and construction, and the continuing pattern of use, many of these buildings survive. There are similarities in their placement, occupying a commanding position in the landscape, their architectural pretensions, and the inclusion of formal rooms for entertaining visitors. The scale and architectural character of each Government House reflects the position of each individual colony within the British Empire.

There is more similarity between Commandant's residences however few survive intact. The single storey house with an encircling verandah is widely believed by architects to be an Australian form. A comparison between Emeric Vidal's 1815 view of the Commodore's House at the Naval Shipyard, Point Frederick, Kingston, Ontario, and Edward Close's 1828 watercolour of the Commandant's Residence, Newcastle, NSW, indicates that there was a standard form, which could be erected in whatever material was at hand. Similar official residences were erected at Risdon Cove in Tasmania and at Windsor in NSW but have long since vanished. The oldest surviving extant example of an official residence in Australia is located on Norfolk Island. The ruins of Lieutenant Foveaux's partially completed residence erected in 1803-04 were completed when settlement was resumed in the late 1820s (figure 4) and continues to be 


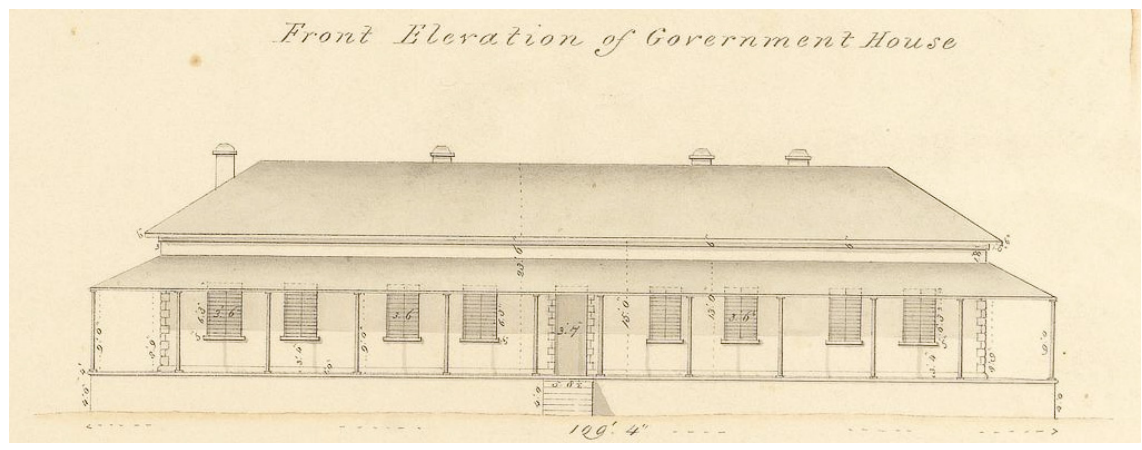

Figure 4: Government House, Norfolk Island, record drawing by Henry Lugard, Royal Engineer, 1839. (Tasmanian Archives and Heritage Office PWD 266/1/1925.)

used as an official residence today. The earliest example of an official residence located with an encircling verandah is Clarence House, Antigua, erected in 1806 for the dockyard officers. The form remained in use, Clarence House is similar in character to civil officers' and superintendent's quarters erected in NSW, Van Dieman's Land (Tasmania) and on Norfolk Island in the 1840s.

\subsection{Officers' quarters}

Civilian quarters were invariably a four-roomed cottage with a verandah and a central hall, which could be used as four single rooms, two separate apartments, or the whole house could be allocated to one high ranking officer. Accommodation for military officers in the barracks complexes was a similar four room arrangement with a central hall, as can be seen in plans of the Wynyard Barracks in Sydney and the Aberdeen Barracks in Scotland. The 'verandah cottage', as this type of building came to be described in the Sydney press, was very influential and was widely copied in civilian housing in the colonies. Surviving quarters at the Anglesea Barracks, Hobart, Tasmania, dating from 1814-1818 indicates that the origins of the verandah cottage in Australia were military. Civilian housing was more vernacular in character.

In Australia, the barrack on Goat Island, initially occupied by the Foreman of the Magazines, is an example of this four-roomed plan. The single storey officers' quarters at the Lancer Barracks at Parramatta (c. 1815) and the now demolished Surgeons' Quarters for the Military Hospital on Observatory Hill (c. 1818), both by Lieutenant Watts, were of this type, as were the prefabricated timber barracks sent to Norfolk Island from the Sydney Lumber Yard in the late 1820s (one of which survives, originally built as the Surgeons' Quarters). We have yet to locate an earlier surviving set of prefabricated quarters in Australasia, the survival rate of buildings erected of timber is much lower than those erected of masonry.

The National Archives in London contains plans for officers' quarters dating from 1800 and 1855 in England and Ireland and the Channel Islands, as well as 
in Africa (Cape of Good Hope and Gambia), British Honduras (Belize), Barbados, Jamaica and St Christopher), Gibraltar and Malta in the Mediterranean, Hong Kong, Canada, New Zealand, Norfolk Island, Mauritius, Sober Island (off Sri Lanka) and Ascension Island. The verandah cottage form continued to be used in the West Indies. At Brimstone Hill Fortress, St Kitts, three stone quarters with verandahs were constructed on top of the existing stone basement to accommodate officers following the destruction of their timber artillery barracks by a hurricane in the 1840 s. This complex is now a world heritage site.

\section{Commissariat stores}

Commissariat Stores were once the most substantial buildings in the Australian colonies and are similar in character to the stores erected at English Naval Victualling Yards. Australia retains commissariat stores in Hobart (1808), Launceston (1828) (now Paterson Barracks), Brisbane (1829) and the later Fremantle Commissariat Stores (1851). The Sydney Commissariat stores, built in 1812, were demolished in 1940. These stores were built directly onto Sydney Cove, with a stone quay located between the loading bays and hoists at each end of the $U$ shaped building. Designed by Lieutenant-Colonel Foveaux, the sandstone commissariat stores were built using convict labour. The Reverend Samuel Marsden used the similar, but smaller, Commissariat stores at Parramatta as a model for the design of the 'stone stores' at Keri, New Zealand and he imported Sydney sandstone for the arches, keystones and quoins.

The Commissariat store at Kingston, Norfolk Island rivalled stores in the major mainland centers in both size and in the quality of its design. The example on Norfolk Island is the only substantial example to survive in the Australian colonies that was not located on a harbour or river frontage, its location selected because of previous problems with high seas and flooding. An influence for the design of the Kingston example may well be the now demolished Royal Naval Victualling Office in East Smithfield, London; the first large victualling yard in England. The similarity in the main stairs between the London Victualling Office and the store at Kingston indicates prior knowledge of English examples. The basement was partly sunk into the ground, as occurred at the Commissariat Stores in Sydney and Parramatta and in the London example.

Commissariat stores were also planned between 1825 and 1850 for Malta and the Ionian Islands in the Mediterranean, Simonstown, King Williamstown, Capetown, Durban, Bloemfontein and in Sierra Leone in Africa, St Ann's, Barbados and Ireland Island, Bermuda, Galle (Ceylon now Sri Lanka) and Montreal, Quebec and Pentanguishene (Lake Huron in Canada). Substantial masonry walls, multi-storey construction and associated quays characterise many of the surviving examples and this building type generally. Surviving examples include the Commissariat store for the garrison at Barbados, built in 1790 (now the power company headquarters) and Bytown Museum (c. 1804), one of the small Commissariat Stores erected on the Rideau Canal, Canada. 


\section{Conclusion}

Buildings designed by the Royal Engineers have had a considerable influence on building forms and technologies employed in civil buildings erected throughout the British colonies during the Georgian and early Victorian eras, however this influence is not reflected in current architectural histories. Forms repeated from colony to colony have not been fully identified but as more architectural drawings become available online this task will become easier. Buildings erected by the Royal Engineers were exceptionally well-designed and well built, having been carefully supervised, and many survive today. The adaptation of standard designs to suit individual colonies is an early form of what is now termed 'environmental design'. These 'loose-fit' designs have proved to be an adaptable and sustainable approach to building. The long-term survival of examples throughout the British colonies has shown that these superior standard buildings are capable of continuing in military use as intended or being adapted over and over again for a wide range of other uses: for tourist and commercial uses, cultural and institutional uses or subdivided for housing.

\section{References}

[1] Pedro Guedes, The Iron Duke's West Indian Barracks, In: J. P. Macarthur and A. Moulis, Additions to architectural history: Additions to Architectural History, XIXth Conference of the Society of Architectural Historians, Australia and New Zealand, Brisbane, October 2002. p. 1.

[2] Captain Brandreth, Royal Engineers, Memorandum relative to a System of Barracks for the West Indies, recommended by Colonel Sir C F Smith, CB $R E$ and approved by the Master-General and Board of Ordnance in Papers on Subjects connected with the duties of the corps of Royal Engineers, QII, London, 1838 pp. 239-246.

[3] Colonel C F Smith, On the Construction of Barracks for Tropical Climates by Captain Smyth, in Royal Engineers papers 1838, as per note [2], p. 236.

[4] Captain Barney's evidence, Sydney Monitor, 7 December 1836.

[5] John Weiler in his Colonial Connections: Royal Engineers and Building Technology Transfer in the Nineteenth Century, Construction History Vol. 12, (1996), p.6.

[6] WT Denison to his mother, quoted in Whitworth Porter, History of the Corps of the Royal Engineers part II, London, Longman, Green \& Co \& New York, p. 289.

[7] Capt H James, Description of the Steam Basin, Docks, and Factory, and other works recently executed in Portsmouth Dockyard in Papers on subjects connected with the duties of the Corps of Royal Engineers. New Series Vol. IIII, 1853, London pp. 77-102. 